Mateusz Szurek* (D), Ewelina Zając*

\title{
Interdyscyplinarne aspekty diagnozy i terapii logopedycznej Łódź, 19 października 2019 roku (sprawozdanie z konferencji naukowej)
}

W dniu 19 października 2019 roku w Łodzi odbyła się konferencja naukowa zatytułowana Interdyscyplinarne aspekty diagnozy i terapii logopedycznej. Została ona zorganizowana przez Zakład Dialektologii Polskiej i Logopedii Uniwersytetu Łódzkiego. Obrady toczyły się w budynku Wydziału Filologicznego UŁ znajdującym się przy ulicy Pomorskiej 171/173. Wydarzenie zostało objęte honorowym patronatem przez Jego Magnificencję Rektora Uniwersytetu Łódzkiego prof. dra hab. Antoniego Różalskiego oraz Prezydent Miasta Łodzi Hannę Zdanowską. Patronat medialny nad konferencją sprawowały TVP3 Łódź oraz Radio Parada.

Konferencję otworzyli: prorektor ds. studenckich dr hab. prof. UŁ Tomasz Cieślak, wicedyrektor ds. naukowych Instytutu Filologii Polskiej i Logopedii dr hab. prof. UŁ Rafał Zarębski oraz kierownik Zakładu Dialektologii Polskiej i Logopedii dr hab. prof. UŁ Irena Jaros.

Tegoroczna konferencja była okazją do spotkania specjalistów różnych dziedzin, w których kręgu zainteresowań znajdują się biologiczne i społeczne uwarunkowania mowy. Wydarzenie dało możliwość ukazania logopedii jako dziedziny o interdyscyplinarnych podstawach oraz przyczyniło się do kontynuacji dyskusji i współpracy

* Uniwersytet Łódzki, Wydział Filologiczny, Instytut Filologii Polskiej i Logopedii, Zakład Dialektologii Polskiej i Logopedii, ul. Pomorska 171/173, 90-236 Łódź, e-mail: mateusz.szurek@uni.lodz.pl, https://orcid.org/0000-0001-5513-2789

** Uniwersytet Łódzki, Wydział Filologiczny, Instytut Filologii Polskiej i Logopedii, Zakład Dialektologii Polskiej i Logopedii, ul. Pomorska 171/173, 90-236 Łódź, e-mail: ewelina.zajac@uni.lodz.pl, https://orcid.org/0000-0002-5076-8347 
specjalistów zajmujących się pomocą dzieciom i dorosłym z zaburzeniami mowy i języka. Do udziału w dyskusji zaproszeni zostali rozmaici specjaliści: logopedzi, audiolodzy, foniatrzy, pedagodzy, psycholodzy, ortodonci, fizjoterapeuci, językoznawcy - pozwoliło to na wieloaspektowe spojrzenie na skomplikowane zagadnienie, jakim jest szeroko pojęta komunikacja. Spotkanie specjalistów tak wielu dyscyplin okazało się bardzo konstruktywne - umożliwiło stworzenie wspólnej wielospecjalistycznej przestrzeni dla diagnozy i terapii na miarę XXI wieku.

Konferencja zgromadziła ponad stu uczestników, reprezentujących różne zawody i profesje, między innymi logopedów, pedagogów, psychologów, lekarzy, nauczycieli wychowania przedszkolnego i edukacji wczesnoszkolnej, fizjoterapeutów oraz liczne grono studentów logopedii. Wygłoszonych zostało trzydzieści siedem referatów. Prelegenci reprezentowali następujące ośrodki naukowe i badawcze: Uniwersytet Łódzki (UŁ), Uniwersytet Gdański (UG), Uniwersytet Warszawski (UW), Uniwersytet Marii Curie-Skłodowskiej w Lublinie (UMCS), Uniwersytet Mikołaja Kopernika w Toruniu (UMK), Uniwersytet Adama Mickiewicza w Poznaniu (UAM), Uniwersytet Kazimierza Wielkiego w Bydgoszczy (UKW), Uniwersytet Śląski (UŚ), Uniwersytet Jana Kochanowskiego w Kielcach (UJK), Uniwersytet Medyczny w Łodzi (UM), Akademię Pedagogiki Specjalnej im. M. Grzegorzewskiej w Warszawie (APS), Państwową Uczelnię im. Stefana Batorego w Skierniewicach, Wyższą Szkołę Pedagogiczną im. J. Korczaka w Warszawie (WSP), Wojewódzkie Wielospecjalistyczne Centrum Onkologii i Traumatologii im. M. Kopernika w Łodzi (WWCOiT), Grupową Praktykę Stomatologiczną w Bolesławcu, Centrum Onkologii - Instytut im. M. Skłodowskiej-Curie w Gliwicach, Niepubliczną Poradnię Psychologiczno-Pedagogiczną „Świętokrzyska” w Kielcach.

Podczas wystąpień plenarnych, którym przewodniczyła dr hab. prof. UŁ Irena Jaros, wygłoszono cztery referaty. Dr hab. prof. UŁ Danuta Pluta-Wojciechowska przedstawiła logopedię na tle i w kontekście lingwistyki, medycyny, pedagogiki i psychologii. Sformułowała również tezę, że spotkanie różnych metodologii może owocować nowym spojrzeniem na diagnozę i terapię osób z zaburzeniami mowy, jednakże z poszanowaniem charakterystycznych dla poszczególnych dyscyplin sposobów analizy objawów i przyczyn dysfunkcji mowy, a także różnych sposobów pomocy. Przedmiotem referatu dra hab. prof. APS Sławomira Śniatkowskiego był sposób wykorzystania słownictwa specjalistycznego z różnych dyscyplin naukowych (medycyna, psychologia, pedagogika, językoznawstwo) w rozwoju teoretyczno-metodologicznych podstaw diagnozy i terapii logopedycznej oraz ukazanie różnic w sposobie postrzegania przedmiotu logopedii i opisie zagadnień logopedycznych (ujęcia multi-, inter- i transdyscyplinarne). Kolejni referenci reprezentujący Uniwersytet Gdański - dr hab. prof. UG Stanisław Milewski i dr hab. prof. UG Katarzyna Kaczorowska-Bray - zwrócili uwagę na to, że problemy komunikowania się osób w wieku senioralnym są niezwykle złożone i nie w pełni zbadane, a wyodrębnienie się gerontologopedii wymaga wypracowania szczegółowej metodologii naukowego poznania 
zmian w komunikacji, towarzyszących starości zarówno fizjologicznej, jak i powikłanej procesami patologicznymi. Ostatnim referentem podczas wystąpień plenarnych był prof. dr hab. n. med. Jurek Olszewski, reprezentujący Uniwersytet Medyczny w Łodzi, który przedstawił przydatność analizy akustycznej i wydolnościowej w ocenie głosu śpiewaczego.

Po wystąpieniach plenarnych obrady odbywały się w czterech sekcjach. W pierwszej prof. dr hab. n. med. Grażyna Śmiech-Słomkowska (UM) omówiła czynności fizjologiczne jamy ustnej, a lek. stom. Monika Ośko, reprezentująca Grupową Praktykę Stomatologiczną w Bolesławcu, przedstawiła zaburzenia funkcji motorycznych jamy ustnej oraz koncepcję hierarchii funkcji motorycznych według filozofii MFS. Następnie dr hab. Natalia Siudzińska (UW) opisała postępowanie terapeutyczne w pierwszych latach życia dziecka z zespołem van der Woude’a. Jest to zespół wad wrodzonych, wśród których występuje rozszczep podniebienia, mający istotny wpływ na rozwój mowy dzieci dotkniętych tą chorobą. Dr n. med. Janusz Konopacki (WWCOiT) podkreślił w swoim wystąpieniu, że logopedia jest interdyscyplinarna i bez szerokiej współpracy specjalistycznej nieskuteczna. Zwrócił także uwagę na zakres autonomiczności pracy logopedy.

W drugiej sekcji dr Marta Wysocka (UMCS) zaprezentowała autorski program służący usprawnianiu percepcji poszczególnych cech i zjawisk prozodycznych. Jego celem jest systematyzacja działań terapeutycznych umożliwiających osobom z dysprozodią oraz tym, które chcą podnosić poziom swoich umiejętności prozodycznych, opanowanie kompetencji i sprawności niezbędnych do rozumienia zjawisk prozodycznych i adekwatnego ich użycia w komunikacji. Następnie dr Agnieszka Hamerlińska (UMK) opisała zjawisko hiposomii u osób po laryngektomii całkowitej. Z kolei mgr Izabela Buczyńska (Centrum Onkologii - Instytut im. M. Skłodowskiej-Curie w Gliwicach) omówiła obraz kliniczny dysfagii popromiennej w ujęciu logopedyczno-medycznym oraz model postępowania diagnostyczno-terapeutycznego oparty na autorskich ankietach, skalach i kwestionariuszach diagnostycznych. Sekcje B zamknął referat lic. Marty Kosickiej (UŁ), w którym przedstawione zostały wyniki badań odnoszących się do wiedzy nauczycieli oraz studentów edukacji wczesnoszkolnej i wychowania przedszkolnego na temat dysfunkcji oraz parafunkcji zespołu ustno-twarzowego.

Sekcję trzecią rozpoczął referat dr hab. Olgi Jauer-Niworowskiej (UW), w którym zostały omówione strategie kompensacyjne stosowane w terapii pacjentów z dyzartrycznymi i/lub komunikacyjno-językowymi zaburzeniami mowy w wyniku zaburzeń struktur podkorowych mózgu. Następnie dr Wojciech Lipski (UMCS) wskazał liczne powiązania między psychologią behawioralną a terapią logopedyczną, zwracając szczególną uwagę na stosowaną analizę zachowania (SAZ). Kolejne referentki - dr Justyna Żulewska (APS) i dr Karolina Pożoga (UJK) - przedstawiły wyniki badań, których celem było oszacowanie stopnia wypalenia zawodowego wśród logopedów z oddziałów rehabilitacji neurologicznej oraz poznanie jego przyczyn. Obrady 
w sekcji zakończyło wystąpienie mgr Aleksandry Szczygieł z Państwowej Uczelni im. Stefana Batorego w Skierniewicach, w którym przedstawione zostały wyniki badań własnych dotyczących świadomości społecznej na temat potencjalnych zagrożeń związanych $\mathrm{z}$ nadużywaniem akcesoriów dziecięcych, a także wnioski dotyczące wagi uwzględnienia problematyki stymulacji przedsionkowej oraz posturalnej w terapii i prewencji rozwoju zaburzeń mowy.

W ostatniej sekcji również wygłoszono cztery referaty. Pierwszy z nich przedstawiła dr Renata Gliwa (UŁ). Omówiła ona fluencję słowną osób z chorobą Alzheimera. W kolejnym wystąpieniu dr Justyna Antczak-Kujawin (UŁ) zaprezentowała wstępne wyniki badań przeprowadzonych przy zastosowaniu kwestionariusza SCAP-A w grupie osób w wieku senioralnym, starzejących się fizjologicznie. Następnie mgr Magdalena Kokot (UG) przedstawiła sposoby wsparcia terapii neurologopedycznej pacjentów po udarze mózgu. Na zakończenie sekcji mgr Justyna Socha (UŁ) zaprezentowała referat poświęcony badaniom empirycznym na temat zaburzeń narracji w otępieniu alzheimerowskim.

Podczas przerw między sekcjami odbywały się sesje posterowe. Plakat dr Urszuli Jęczeń (UMCS) dotyczył roli definicji kognitywnej w procesie diagnozowania kompetencji językowej (na poziomie sprawności semantycznej, leksykalnej i składniowej) dzieci w normie i osób niepełnosprawnych intelektualnie. Mgr Kamila Szpyra (UŚ) na swoim posterze przedstawiła wpływ MPD na kompetencję narracyjną u osób dorosłych, natomiast plakat mgr Aleksandry Jastrzębowskiej-Jasińskiej (WSP) dotyczył zastosowania modelu podatność-stres w programowaniu terapii niepłynności mówienia.

Obrady popołudniowe również zostały podzielone na cztery sekcje. W pierwszej swoje wystąpienia zaprezentowali: dr Aneta Wojciechowska (UAM), dr Ewa Gacka (UŁ), dr Maria Faściszewska (UG), mgr Łukasz Kowalczyk (APS) oraz lic. Krystian Manicki (UKW). Wystąpienie pierwszej z referentek miało na celu wskazanie podobieństw i różnic między alalią a zaburzeniem ze spektrum autyzmu, ze szczególnym uwzględnieniem rozwoju mowy. Dr Gacka przedstawiła referat na temat profilaktyki logopedycznej II stopnia skierowanej na dzieci z małą urodzeniową masą ciała. Dr Faściszewska swoje wystąpienie poświęciła zagadnieniom związanym z diagnozą jąkających się dzieci w wieku przedszkolnym i młodszym wieku szkolnym. Skupiła się na przedstawieniu najczęściej występujących trudności u dzieci jąkających się oraz szczegółowo omówiła problematykę diagnozy i kryteria obserwacji dziecka. Temat kolejnego wystąpienia również dotyczył zagadnienia związanego z jąkaniem. Mgr Kowalczyk przedstawił zmodyfikowaną wersję modelu góry lodowej Sheehana, aby opisać istotę jąkania w procesie diagnostyczno-terapeutycznym. Ostatni referat w tej sekcji, wygłoszony przez lic. Krystiana Manickiego, dotyczył natomiast zaburzeń rozwoju mowy dziecka z mózgowym porażeniem dziecięcym.

Obrady w drugiej sekcji rozpoczęły dr Joanna Zawadka, dr Marlena Kurowska i dr Elżbieta Sadowska (UW), które w swoim wystąpieniu zwróciły uwagę 
na wybrane kwestie problemowe związane z właściwym rozpoznaniem złożoności sytuacji językowej dzieci dwujęzycznych w trakcie diagnozy logopedycznej. Autorki przedstawiały także propozycję kwestionariusza przeznaczonego dla logopedów, który umożliwi im bliższe poznanie sytuacji, w jakiej dokonuje się przyswajanie obu języków przez dziecko. Drugi z referatów, autorstwa dr Michaliny Biernackiej (UŁ), także poświęcono glottodydaktyce - jego celem było zaprezentowanie zakresu, w jakim wiedza glottodydaktyczna może przydać się w codziennej pracy logopedy. Dr Joanna Jatkowska (UKW) poruszyła temat zastosowania nowych technologii w terapii logopedycznej dzieci z zaburzeniami mowy, a także omówiła własne doświadczenia dotyczące korzystania z logopedycznej platformy e-learningowej.

Wśród referentów obradujących w trzeciej sekcji znalazły się dr hab. Katarzyna Jachimowska i lic. Paulina Pawłowska (UŁ). Zaprezentowały one referat dotyczący psychologicznych i językowych uwarunkowań nabywania znaczeń wyrazów przez dzieci w wieku przedszkolnym. Następnie dr Monika Kaźmierczak (UŁ) przedstawiła wykorzystanie metody P4C (ang. Philosophy for Children) Matthew Lipmana $\mathrm{w}$ definiowaniu pojęć przez dzieci w wieku przedszkolnym. Kolejna referentka - dr Izabela Ejsmunt-Wieczorek (UŁ) - wygłosiła referat na temat polisemantyzmów w zasobie leksykalnym dzieci przedszkolnych. W wystąpieniu mgr Anny Karowicz (Państwowa Uczelnia im. Stefana Batorego w Skierniewicach) przedstawione zostały argumenty przemawiające za tym, że kompleksowa diagnoza jest niezbędnym elementem terapii logopedycznej, zwłaszcza dzieci z opóźnionym rozwojem mowy.

W ostatniej sekcji dr hab. prof. UKW Dorota Podgórska-Jachnik poruszyła problem nieśmiałości w odniesieniu do mutyzmu wybiórczego, zwracając uwagę na diagnostykę różnicową i strategie wspierające funkcjonowanie dziecka. Następnie dr hab. prof. UŁ Renata Marciniak-Firadza omówiła diagnozowanie i metody terapii dziecka/ucznia z mutyzmem wybiórczym, a dr Ewa Kos (UŁ) przedstawiła specyfikę tego zaburzenia $\mathrm{w}$ kontekście funkcjonowania dziecka $\mathrm{w}$ środowisku pozarodzinnym. Wystąpienie mgr Alicji Chilińskiej-Pułkowskiej (UG) dotyczyło komunikacji osób z głęboką niepełnosprawnością intelektualną. Obrady w sekcji zakończyłowystąpieniemgra TomaszaWiecha(NiepublicznaPoradniaPsychologiczno-Pedagogiczna „Ŝwiętokrzyska” w Kielcach) na temat terapii zaburzeń języka i mowy chłopców z zespołem kruchego chromosomu X.

Podsumowania konferencji dokonała dr hab. prof. UŁ Irena Jaros, która podziękowała prelegentom i słuchaczom za udział w obradach i dyskusjach. Po zakończeniu konferencji uczestnicy wzięli udział w pięciu warsztatach przeprowadzonych przez: dr Agnieszkę Hamerlińską (Mowa przełykowa i przetokowa, czyli o terapii logopedycznej osób po laryngektomii całkowitej), mgr Dominikę Kozłowską-Wojnar (Zaburzenia mowy, zaburzenia przełykania, rurka tracheotomijna u pacjentów po leczeniu onkologicznym nowotworów jamy ustnej), mgr Aleksandrę Wojciechowską (Wpływ małej i dużej motoryki na rozwój mowy w aspekcie terapii integracji sensorycznej), mgr Ewelinę Retelewską-Guc (Dobór odpowiednich pozycji do karmienia w oparciu 
o metody neurofizjologiczne na podstawie własnych doświadczeń) oraz mgr Monikę Knychalską-Zbierańska (Trening stuchowy, wzrokowy i motoryczny - Metoda Warnkego i jej rola/miejsce $w$ diagnozie i terapii logopedycznej).

Uczestnicy konferencji stworzyli doskonałą atmosferę do wymiany myśli naukowej. Spotkanie stało się także okazją do nawiązania współpracy między specjalistami, którym bliskie są zagadnienia związane z logopedią, podkreślając tym samym jej interdyscyplinarność. 